\title{
THE RIGHT TO HEALTH AND ENVIRONMENT IN TIMES OF SOCIAL EXCLUSION
}

\author{
Liliana Angel Vargas ${ }^{1}$ \\ Thaís Fonseca Veloso de Oliveira ${ }^{2}$ \\ Júlia Arêas Garbois ${ }^{2}$
}

Vargas LA, Oliveira TFV, Garbois JA. The right to health and environment in times of social exclusion. Rev Latino-am Enfermagem 2007 setembro-outubro; 15(número especial):850-6.

This article is a theoretical reflection on the trajectory of the right to health and to the environment in the political Brazilian scenario and in the health sector. It aims to discuss the possibilities of these rights to be effectively guaranteed, out of the rhetorical sphere, in order to structure a fairer and healthier society. We observed that the Brazilian scenario evidences that the complex problems associated to the environmental and health injustices are materialized in social exclusion and environmental degradation, compromising these rights. We concluded that the assurance of these rights is linked to the possibilities of a collective achievement of the Brazilian society, to which Nursing can provide an important contribution.

DESCRIPTORS: health; environment; right to health; environmental health; public health; universal access to health care services; health inequalities; social inequity

\section{EL DERECHO A LA SALUD Y AL MEDIO AMBIENTE EN TIEMPOS DE EXCLUSIÓN SOCIAL}

Esta es una reflexión teórica sobre la trayectoria política de estos derechos en el escenario político brasileño y dentro del sector salud, y tiene como objetivo discutir las posibilidades de que estos sean efectivamente garantidos, saliendo de la esfera retórica, estructurando una sociedad más justa y saludable. Observamos que la realidad brasileña denuncia que los complexos problemas asociados a la injusticia social y ambiental se materializan en la exclusión social y la degradación ambiental, comprometiendo estos derechos. Concluimos que la garantía de estos está ligada a la posibilidad de conquista colectiva de la sociedad brasileña, en la cual la Enfermería puede dar una importante contribución.

DESCRIPTORES: salud; ambiente; derecho a la salud; salud ambiental; salud pública; acceso universal a servicios de salud desigualdades en la salud; iniquidad social

\section{O DIREITO À SAÚDE E AO MEIO AMBIENTE EM TEMPOS DE EXCLUSÃO SOCIAL}

Este artigo é uma reflexão teórica sobre a trajetória do direito à saúde e ao meio ambiente no cenário político brasileiro e dentro do setor saúde, e tem como objetivo discutir as possibilidades de que esses direitos sejam efetivamente garantidos, saindo da esfera da retórica, estruturando uma sociedade mais justa e saudável. observa-se que a realidade brasileira denuncia que os complexos problemas associados à injustiça social e ambiental se materializam na exclusão social e degradação ambiental, comprometendo esses direitos. Concluise que a garantia desses está ligada às possibilidades de conquista coletiva da sociedade brasileira, na qual a Enfermagem pode dar importante contribuição.

DESCRITORES: saúde; meio ambiente; direito à saúde; saúde ambiental; saúde pública; acesso universal a serviços de saúde; desigualdades em saúde; iniqüidade social

${ }^{1}$ PhD in Collective Health, Adjunct Professor, email: lilianaangel@globo.com; ${ }^{2}$ PIBIC scholarship holder, Graduate Student in Nursing, e-mail: tfvo@hotmail.com, juliagarbois@hotmail.com. College of Nursing Alfredo Pinto, Rio de Janeiro Federal University 


\section{INTRODUCTION}

The Brazilian Constitution of 1988 , also known as the Citizen Constitution, included fundamental aspects in the Brazilian political agenda regarding the analysis of the complexity of social dynamics: the right to health and environment.

This article aims to discuss the real possibilities of guaranteeing the right to health and environment, both recognized in Brazil's 1988 Constitution, respectively in articles 196 and 255, within the Brazilian political setting, which is marked by social inequality and daily expressions of non citizenship. Hence, we proposed to carry out a theoretical reflection about the political history of the right to health and environment, particularly within the health sector, where this discussion has undergone advancements as well as regressions. Advancements, in this case, are largely within the discourse or "rhetorical" dimension, but with few achievements in practice.

This discussion was founded on pertinent literature about the subject, which included authors like Amelia Cohn, Sarah Escorel, Henri Acselrad, Pedro Demo, and others. In addition to the referred studies, a survey was carried out on the Constitution of the Federative Republic of Brazil, as well as the knowledge obtained through the research projects Health, Environment and Citizenship: an integration of education, research and extension and The Right to Health in times of Social Exclusion. These research projects were developed by a group formed by a faculty member and students from Alfredo Pinto College of Nursing at Rio de Janeiro State Federal University.

We will start this reflection by analyzing the limits and possibilities of the right to health and environment. Next, we will associate them with the history of relationships between environment and health, which are far from being understood as structuring aspects in the health/disease process and, therefore, essential to environment and human health promotion.

\section{THE RIGHT TO HEALTH IN THE BRAZILIAN POLITIC CONTEXT}

The extended health concept, formulated by the Sanitation Movement and legitimized in the
Brazilian health policy at the VIII National Health Conference in 1986, unquestionably brought about an intricate relationship between health and the citizenship level of the country's population. From a legal standpoint, the 1988 Brazilian Constitution states in article 196 that "health is a right for all and a responsibility of the State", guaranteed through social and economic policies that aim to reduce the risks for disease and other ailments, and to provide equal access to service and actions to promote, protect and recover health ${ }^{(1)}$ (author's emphasis).

Brazil currently holds the $10^{\text {th }}$ position in the global economy ranking and is acknowledged in the international setting as one of the richest Latin American countries. This recognition is a result of its economic and industrial history and its exuberant biodiversity. However, these riches are not justly and equally distributed among the country's citizens, generating tension and conflicts due to social inequities and inequalities.

This inequality is expressed as different forms of opportunities of access and insertion in the productive process, as well as in the possibility of picking the benefits of this process. Hence, according to the Commission for Social Health Determinants, these differences "point to the specific characteristics of social contexts that affect health, as well as to the form these social conditions translate this impact on health" ${ }^{\prime 2}$. In other words, they express inequities of the social dynamics, particularly if the development model adopted by society puts economic development before social development.

The II International Conference for Health Promotion, held in Adelaide, Australia, in 1988, appointed that health inequities stem from social inequalities, and should be overcome with policies that seek to provide socially and educationally deprived people with better access to social assets and services.

On the other hand, social inequality also reflects on people's position regarding what they consider to be their rights and possibilities of action. For the more privileged part of the population, "rights are, though vaguely, the formal guarantee of predetermined rights" ${ }^{\prime \prime}(3)$, whereas the deprived party confuses the idea of right with that of gift or favor, which, in turn, immobilizes the possibilities of fighting and revindicating current as well as new rights. This consequently puts the exclusive interests of an elite minority over those representing the majority of the population. 
Therefore, it is considered that inequality in Brazil is structural and that poverty is not limited to economic needs; rather, it is associated with submission as well as political and social poverty. In this sense, we agree with authors ${ }^{(3)}$ who state that "due to the current cultural policy in Brazil, patrimonial and authoritarian, exchanged between regimens that undervalue citizens, Brazilians live two difficult experiences: learning what democracy is, and their paths toward establishing citizenship. Since the population is used to living with a State that is deaf to their demands, the collective perception about the current possibilities of action are reduced and the notion of rights as State donations is perversely maintained".

Social inequality supports and is supported by a society model that appears to be willing to pay the price for its omission. This generates growing and dynamic processes of socio-environmental unsustainability, injustice and social exclusion, which are expressed through poverty, discrimination, prejudice, violence, and others.

Data from the Brazilian Institute of Geography and Statistics (IBGE), in 2003, show that the gross domestic product (GDP) in Brazil grew 100 fold over the last century. This is the reason why the country figures among those with the best development in Latin America. However, it is also the country that has most concentrated and least distributed its riches among citizens. In this sense, we agree that "it is not a poor country, but there is a significant number of poor people throughout its territory". For this author, "the term 'poverty' implies not only a state of material deprivation, but also a lifestyle - and a complex and enduring group of social, economic, cultural and political relations and institutions created to find security in an insecure situation"(4) (author's emphasis).

Concerning this perspective, it should be emphasized that "what calls attention is the constitution of a place in which the equality promised by law reproduces and legitimizes inequalities; a place that builds signs of civil belonging, but contains within itself a principle that excludes majorities; a place that announces establishing social justice, but blocks the equalitarian effects of civil rights in the plot of social relationships" ${ }^{\prime(5)}$.

Hence, the reconfiguration/rearticulation of State-population relationships in a neoliberal context becomes the great challenge to be faced when private domain rules and principles prevail over those of public domain and, consequently, the notion of citizen rights is replaced with that of consumer's rights $^{(6)}$

Therefore, we understand that it is mandatory to reaffirm the importance of democracy and citizenship as a sine qua non condition to level inequalities through public policies, mainly social policies. However, adopting a neoliberal model in State-society relationships in Brazil, instead of overcoming its substantial social inequalities, has aggravated them, perpetuating injustices and increasing social conflicts. Thus, in this context, social exclusion emerges.

The term social exclusion appeared in the 1970s in the book by Lenoir (1974), who denounced the progress-forgotten population: prisoners, the mentally impaired, the handicapped, elders, and others $^{(7)}$. However, today we experience what could be called social exclusion "globalization", since this phenomenon has crossed the borders of different countries and regions in the world, at every level.

In Brazil, social exclusion is intimately associated with cultural, political and social inheritances that gave rise to an unequal, discriminatory, prejudiced society. That society has crystallized conflicting relationships in a setting where conflict negotiation has been historically replaced by authoritarianism, omission, and negligence. This has originated an array of non citizenship expressions, which, in some people, generate screams of insurrection, but what truly prevails is the population's silent or silenced suffering.

Therefore, we consider that "social exclusion is not characterized only by extreme material deprivation. Rather, it is mainly portrayed by the disqualification caused to individuals, in the sense that it takes away the quality of being a citizen, Brazilian, and a human being, with legitimate desires, wills and interests, and is identified and distinguished through them" ${ }^{\prime(8)}$ (author's emphasis).

This unprivileged group, living in locations associated with social exclusion, consists of approximately $21 \%$ of the Brazilian population ${ }^{(9)}$ and "represents populations pushed to the margins of social life, and which carry the burden of part of the world's misery"; "they are aware that the future will take place without them" and "they belong to declining social groups and express disorder, which also has a collective dimension" ${ }^{(10)}$. 
In addition, these social groups are also deprived of the right to sanitary water, clean air, basic sanitation, land security and dignified housing conditions. In other words, this population no longer suffers from a single kind of injustice, but, in fact, they suffer from overlapping injustice, which characterizes environmental injustice. The latter is understood as the mechanism by which the heaviest burdens of environmental hazards caused by development are imposed on low income populations, discriminated ethnic groups, traditional ethnic people, working-class neighborhoods, and marginalized and vulnerable populations"(11).

Thus, the degradation of natural ecosystems, water and soil resources is a consequence of the impacts produced by industrial waste, excessive pesticides, mining, monoculture and other strategies adopted as a result of the stimuli exerted by the market and those with political and economic power. This constitutes a constant situation of socioenvironmental injustice in Brazil ${ }^{(11)}$.

It is clear that many obstacles in the Brazilian society should be overcome to guarantee the right to health or any other expression of citizenship, as well as the possibility of revindicating it. In this sense, there is a long road ahead to reach a level of dignified life, where health is the expression of justice and social inclusion.

\section{THE RIGHT TO ENVIRONMENT IN THE BRAZILIAN POLITICAL CONTEXT}

As a result of technological innovations, as from the Industrial Revolution, there has been an exploitation of natural, water, and soil resources that surpasses the regenerative capacity of ecosystems and renewable natural resources. This has led to a level of exhaustion, generating negative side effects that are increasingly complex and unpredictable, and generally linked to environmental issues ${ }^{(12)}$.

Hence, we understand that the environmental issue is a conflict between State, nature and society. In the case of Brazil, it is a result of adopting a predatory and excluding model of development, which has led people, communities and ecosystems, among others, to exhaustion. Moreover, it has confirmed the incontestable relationships between health and environment.

From a legal standpoint, like health, the environment is also a right of all, as expressed in article $22^{\text {nd }}$ of the Brazilian Constitution, which states that "all have the right to an ecologically balanced environment, an asset to be equally used be the people, and essential to a healthy quality of life; it is the responsibility of the Public Power and the community to protect the environment for the present and future generations ${ }^{\prime \prime}(1)$. There are contradictions between this regulation and reality, since the environment, here understood as a public asset which we all have the right to use and the responsibility of protecting simultaneously constitutes an essential requirement for health and quality of life. There is also an expression of transgeneration responsibility, an essential presumption of sustainable development, enunciated by the World Commission on Environment and Development in 1987, through the report Our Common Future.

However, in article 225, the concept of environment is still linked to the physical-natural environment, apart from social dynamics and, therefore, conflicting with the essential principles of sustainable development. Hence, "the formal conception of the State as manager of natural patrimony and promoter of environmental quality disagrees with the traditional functions of the Brazilian developmentalist State" ${ }^{\prime(11)}$ (author's emphasis).

In this sense, environmental investments, a product of national and international funding obtained through different institutions - including the World Bank, the Inter-American Development Bank (IDB) and the Brazilian Development Bank (BNDES) - are usually focused on just-in-time work. Despite their importance, these works have no association with any other series of aspects that comprise the whole and parts of social dynamics. Hence, their impact is zero and, worse, in many cases negative.

On the other hand, the symbolic effect is that solutions for social problems are solved with engineering. This means there is negligence regarding the possibility of seeing environmental issues as associated with structural and conjectural macroprocesses, due to the strict relationship with the social contract established between State and society.

\section{ENVIRONMENT/HEALTH RELATIONSHIPS IN THE BRAZILIAN POLITICAL CONTEXT}

In the Brazilian health sector, where this discussion remains a peripheral trend, the 
environmental dimension is acknowledged as one of the health determinants, incorporated in the extended health concept formulated by the Sanitation Movement and legitimized at the VIII National Health Conference in 1986. This concept, besides providing a better understanding about the interdisciplinary and intersectorial responsibility in social health production, elevates health to the level of social right and quality of life. The latter is not associated with sophistication or glamour, but concerns access to dignified living conditions.

Therefore, we agree with some authors'(13) proposals that quality of life is understood as "the sum of economic, environmental, scientific-cultural and political conditions. These conditions are collectively constructed and made available so that individuals can accomplish their potentialities $[\ldots] "$ ". This includes: access at several moments and in several situations to production, information, as well as the participation in making decisions that induce improvements to community living conditions.

In Brazil, as from the 1980s, but especially in the 1990s, the incontestable environment-health relationship began to be formalized within the health sector, at least at the normative level. However, we understand that this precept cannot be limited to this stage; it presupposes a broader understanding of both categories - environment and health - inexorably influenced by the same economic, political, cultural and socio-environmental context. It also presupposes the possibility of an institutional and intersectorial dialogue, in which the various actors involved establish mediation, articulation and commitment relationships, due to the challenges brought about by the residual effects of a predatory and unequal development process.

Unquestionably, this discussion, "new" to the health sector, had the opportunity, at the United Nations Conference on Environment and Development - better known as "Rio-92", to become an important landmark of political mobilization. In fact, the Agenda 21 , the main document of the referred event, dedicates the sixth chapter to health, under the title "Protection and Promotion of Human Health Conditions".

Hence, a plan was designed capable to help the several governments in accomplishing efforts to guarantee environmental health. The World Health Organization was appointed as the most appropriate institution to coordinate the various activities to achieve this goal. However, the poor development of the environmental discussion, within the sector, caused even the most progressive collective health segments to remain at a rather peripheral position regarding Rio-92.

Shortly after this conference, the PanAmerican Health Organization (PAHO) decided to hold, in 1995, the Pan-American Conference on Health, Environment, and Development (COPASAD), "[...] with the purpose to define and adopt a set of health and environment policies and strategies, as well as to elaborate a Regional Plan of Action in the context of sustainable development"(14). To honor the commitment of Brazil's participation, the government created the Interministerial Commission for Sustainable Development (CIDES), which should counsel Brazil's President regarding the feasibility of implementing the commitments assumed by the country at Rio-92. However, this commission was not formally established until 1997, two years after COPASAD took place.

Therefore, the responsibility of participating in the COPASAD fell on the Intersectorial Workgroup (GTI), created in 1994 by President Itamar Franco. The GTI was coordinated by the Ministry of Health, which, with support from PAHO and the United Nations Children's Fund (UNICEF), held four workshops. At the end of the workshops, the National Environment and Health Action Plan (NEHAP) was elaborated and published by the Ministry of Health in 1995. The Brazilian government adopted the Plan as the country's official document in the COPASAD.

Adopting the three principles of the Brazilian Public Health System (SUS) - universalization, equity and integrality-, this plan was characterized by the poor objectivity and ambiguity of its proposals, which have not been put in practice until this day. The delay for its implementation was due to the Brazilian government's lack of structure to create integrated actions that would assign logic and coherence to public health and environment actions, as well as the impossibility of conducting and organizing them ${ }^{(15)}$.

Over the last years, there has been a significant increase in forums that address healthenvironment interrelations. There have been discussions about a range of issues - from environmental degradation and pollution to the threat of water shortage for a great number of inhabitants in the $21^{\text {st }}$ century. Nevertheless, the discussion contents maintain a technicist and reductionist bias, 
and there has been little advancement to a more political and ethical approach that would permit visualizing, in the short and long terms, real possibilities of change.

Thus, "creating health-favorable environments implies recognizing the complexities of our societies and the interdependence relationships between various sectors $[\ldots]^{\prime \prime(16)}$. For this author, protecting the environment and conserving natural resources should be incorporated in the permanent health agenda. Hence, addressing the environmental issue, today, takes on fundamental relevance for all social sectors. That includes the health sector, which faces the challenge of definitely incorporating this dimension in the analysis about the health/disease process, as well as structuring discourses and practices aimed at human and environmental health promotion.

Therefore, the challenge is set within the health sector, so that professionals in this area, including nursing, become involved in a collective, interdisciplinary and intersectorial proposal, which is based on the structuring of partnerships among various social segments. The focus of the proposal is to protect health and the environment, that is, protect life, in every form and stage.

\section{CONCLUSION}

It is important to emphasize that it was through the 1988 Brazilian Constitution that health and environment in Brazil were acknowledged as civil rights and as being intimately associated with citizenship levels and quality of life. In this sense, it is legitimate to relate this conquest to the political process that brought about the country's redemocratization. However, Brazil undergoes a conflict democracy, which "[...] does not presuppose an organized society, but a very disorganized one, divided between integrated and marginalized individuals $[\ldots]^{\prime \prime(17)}$. This is the reason why rules and procedures should be used to make conflicts tolerable, without necessarily resolving them.
In the same sense, some authors ${ }^{(9)}$, when referring to the "national geography of social exclusion", state that they conclude that "throughout the $5^{\text {th }}$ largest territory in the world, there are few social inclusion 'camps' amidst a broad exclusion 'jungle', which covers nearly the entire Brazilian area" (author's emphasis). In addition, the referred exclusion "jungle" is simultaneously affected by environmental injustice, expressed through the greater exposure to a negative environmental burden of populations that are also more fragile and face a higher social risk.

Therefore, the Brazilian reality denounces that these large, complex issues associated with social and environmental injustice are materialized in social exclusion and environmental degradation. Moreover, they reveal the distant and intricate road to be followed in order to move these rights from the normative and rhetorical domain to the everyday reality of the Brazilian population.

In this sense, the XII Sergio Arouca National Health Conference, a privileged forum to think about health policy in the Brazilian State context, held in 2003, proposed to (re)discuss the right to health, under the motto "Health: a right for all and a responsibility of the State; The health we have, the SUS we want". At this conference, it was pointed out that, to make the right to health effective, "the multidimensional spiral must be broken, which characterized these various exclusions processes - a product of the macroeconomic policy ${ }^{(18) "}$.

Hence, "among the many difficulties, derived from political, economic, social and cultural factors, nurses should continue fighting for people's quality of life. Moreover, they should continue working as multiplying agents of knowledge and humanized actions, as well as mobilizing common activities between civil society and the State" ${ }^{\prime(19)}$.

Therefore, we understand that the guarantee of the right to health and environment is strongly linked to the Brazilian society's possibilities of collective conquests, based on the ethical principle of encouraging and protecting life in the present and future generations. Unquestionably, the health sector, nursing included, can contribute enormously to face this challenge.

\section{REFERENCES}

1. Constituição [da] Republica Federativa do Brasil. Brasília (DF): Senado Federal; 1988.
2. Comissão de Determinantes Sociais de Saúde (CDSS). Rumo a um Modelo Conceitual para Análise e Ação sobre os Determinantes Sociais de Saúde. Genebra: Organização Mundial de Saúde; 2005. 
3. Machado FRS, Pinheiro R, Guizard FL. Direito à Saúde e Integralidade no SUS: o exercício da cidadania e o papel do Ministério Público. In: Pinheiro R, Araújo R organizadores. Construção Social da Demanda: direito à saúde, trabalho em equipe, participação e espaços públicos. Rio de Janeiro (RJ): Cepesc/UERJ, Abrasco; 2005.

4. Teles N. A construção social da pobreza pela saúde pública (1918-1922 e 2002). In: Balsa C, Beti L, Soulet M, organizadores. Conceitos e dimensões da pobreza e da exclusão social: uma abordagem transnacional. Ijuí (RS): Ed. Ijuí; 2006. p.201-24.

5. Telles VS. Direitos sociais: afinal do que se trata? Belo Horizonte (MG): UFMG;1999.

6. Cohn A. Estado e sociedade e as reconfigurações do direito à saúde. Ciênc Saúde Coletiva 2003; 8(1):9-18.

7. Demo P. O charme da exclusão social. Campinas (SP): Autores Associados; 1998.

8. Escorel S. Exclusão Social e Saúde. Rev Saúde em debate 1994 junho; (43).

9. Pochmann M, Amorim R, organizadores. Atlas da exclusão social no Brasil. 3 ed. São Paulo (SP): Cortez; 2004.

10. Balsa CM, Boneti LW, Soulet MH, organizadores. Conceitos e dimensões da pobreza e da exclusão social: uma abordagem transnacional. Ijuí (RS): Ed. Unijuí; 2006.

11. Acselard $H$, organizador. Justiça ambiental e cidadania. Rio de Janeiro(RJ): Relume Dumará: Fundação Ford; 2004.

12. Silva ER, Schramm FR. A questão ecológica: entre a ciência e a ideologia/utopia de uma época. Cad. Saúde Pública 1997 julho-setembro; 13(3).

13. Herculano S, Porto MFS, Freitas CM, organizadores. Qualidade de vida e riscos ambientais. Niterói (RJ): EDUFF; 2000 .

14. Porto MF. Saúde, ambiente e desenvolvimento. Ciênc Saúde Coletiva 1998; 3(2):33-46.

15. Pagnoccheschi B. O plano nacional de saúde e ambiente: iniciativas ainda no papel. Rev Debates Sócio-ambientiais: meio ambiente e saúde $1998 ; 3(8): 3-5$.

16. Buss PM. Promoção da saúde e qualidade de vida. Ciênc Saúde Coletiva 2000; 5(1):163-77.

17. Weffort F. Qual democracia? São Paulo (SP): Companhia das Letras; 1992. $165 \mathrm{p}$.

18. Ministério da Saúde (BR). 12a Conferência Nacional de Saúde: Conferência Sérgio Arouca. Brasília (DF): Ministério da Saúde; 2005.

19. Mendes IAC. A saúde no Brasil e América Latina: as metas do milênio da ONU e o papel da enfermagem. Rev Latino-am. Enfermagem 2004 novembro-dezembro; 12(6):845-50. 